\title{
Food, Markets and Nutrition: Maximizing the Impacts of Private Sector Engagement in Tanzania
} Case studies and key messages from the workshop 9 April 2015

\section{Contents}

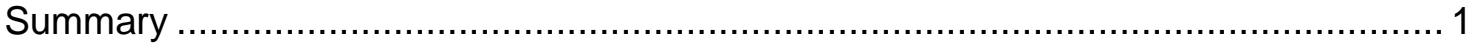

IDS work on markets, business and nutrition ..................................................... 1

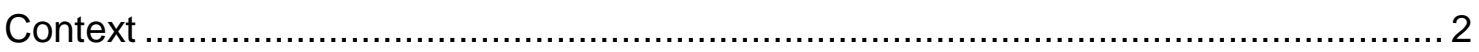

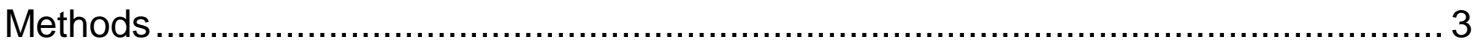

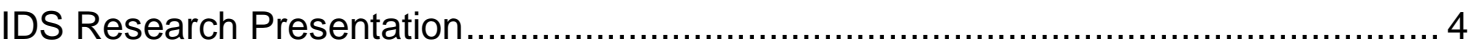

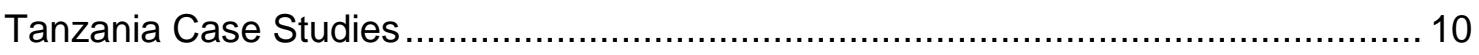

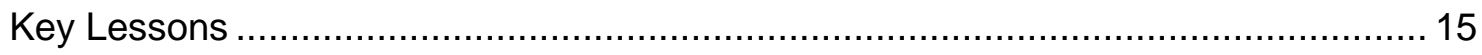

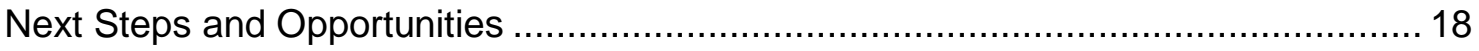

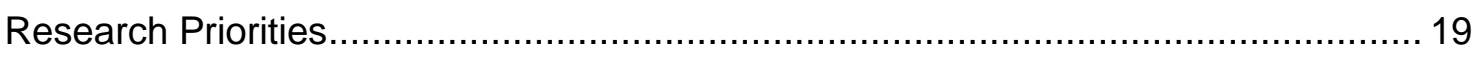

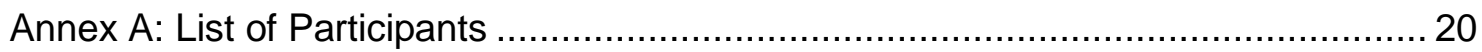

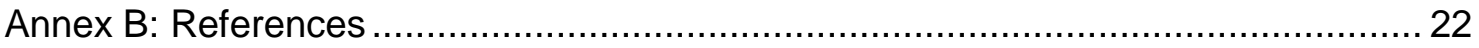

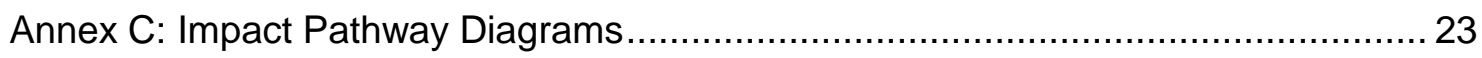




\section{Summary}

This report summarizes the findings of a workshop for representatives of Tanzanian government, development partners, civil society and private sector organisations, hosted by the Institute of Development Studies (IDS) on 30 March 2015. The workshop focused on strengthening the impacts of market-based approaches for improving nutrition in Tanzania, including improving ongoing initiatives and developing the next generation of programmes and supportive policies. Drawing on IDS research, it provided an overview of the key constraints facing markets and nutrition and the options to address them. It provided participants an opportunity to undertake market systems analysis of real case studies from Tanzania. The workshop concluded by identifying priority issues and gaps that affect programmes in Tanzania. Participants collectively identified the following three priorities for future programme development and policymaking:

1. There is a need for new and more effective processes and structures for enforcement.

2. Public awareness and trust (particularly in processed foods) is needed at the national scale, beyond the direct influence of particular projects.

3. There is a need for better structures for coordinating programs that involve multiple actors and different sectors (public/private/CSO).

The outcomes of the workshop were presented to key stakeholders and members of the media and public on Tuesday, 31 March. Several potential opportunities were identified for Tanzanian stakeholders to highlight these priorities and recommend actions as part of ongoing policy processes. The IDS team will respond to these themes in ongoing evidencebuilding and policy advising during 2015-16, focusing on research questions that respond to stakeholder priorities.

\section{IDS work on markets, business and nutrition}

The Institute of Development Studies (IDS) is a leading global institution for development research, teaching and learning, and impact and communications, based at the University of Sussex, UK. Our present vision is a world in which poverty does not exist, social justice prevails and economic growth is focused on improving human wellbeing. We believe that research knowledge can drive the change that must happen in order for this vision to be realised.

IDS leads a portfolio of work on the role of businesses and markets in reducing undernutrition, including the 'Strengthening Agri-food Value Chains for Nutrition' project. Since 2012, the IDS team has worked in Ghana, Nigeria and Tanzania. Activities have included assessing nutrition opportunities in various agri-food value chains, conducting case studies of business action on nutrition and providing policy advise and recommendations to stakeholders in governments, development agencies, civil society and the private sector. In Tanzania, IDS has worked in partnership with Prof. Anna Temu in the Department of Agricultural Economics and Agribusiness, Sokoine University of Agriculture. The project has been funded by the UK Department for International Development.

For more information and a list of publications, visit: http://www.ids.ac.uk/project/strengthening-agri-food-value-chains-for-nutrition 


\section{Context for Food Markets and Nutrition in Tanzania}

Tanzania faces a major undernutrition problem, with unacceptably large numbers of children suffering from chronic deficiencies in key micronutrients such as iron, vitamin $A$ and zinc. Children under 2 years old and women of child-bearing age are the most vulnerable to the negative health consequences of undernutrition. The problem is particularly severe among lower income groups and people living in rural areas. The Government of Tanzania has made nutrition a national policy priority, as signalled by Tanzania's status as one of the first members of the Scaling Up Nutrition (SUN) Movement in 2011. The Government aims to reduce undernutrition through a multi-sectoral strategy, including efforts to supply foods rich in micronutrients through the national fortification programme and through agricultural programmes.

Both in Tanzania and globally, nutrition policy has shown a recent trend towards producing and delivering nutrient-rich foods through market-based approaches and partnerships between public and private sector organisations. In Tanzania, the National Food Fortification Alliance represents one such approach that has attracted support from Government, development partners and large food manufacturers. Agricultural policies targeting nutrientrich crops and promoting commercial agriculture also aim to shape agri-food markets in order to improve nutrition. Yet evidence from Tanzania and elsewhere suggests that such programmes - in their current form - may not reach the majority of Tanzanians, with low income Tanzanians particularly vulnerable to not being able to access sufficient nutrient-rich foods. For example, as currently implemented, food fortification covers products made by large, formal sector manufacturers, but does not cover small-scale production (e.g. of vegetable oil or maize flour). Poor and/or rural populations are most likely to source products from small-scale producers and informal enterprises and thus fortification is not reaching many of the poor. Government agencies and development projects alike have struggled to enable small and medium enterprises (SMEs) to undertake fortification.

In the future, markets will become increasingly important as a source of food for many Tanzanians, aided by rapid urbanisation and changing livelihoods. There is therefore a need for more effective, sustainable and equitable approaches for shaping these markets in order to improve the nutritional quality of foods. Developing these approaches requires understanding of the challenges and gaps facing current programmes, identifying where market-based approaches are most effective and highlighting how stakeholders can focus their efforts in order to enable systemic change. The workshop aimed to respond to these needs, and was designed to achieve the following objectives:

- Contribute to the design and implementation of market-based approaches to nutrition by systematically drawing together experience from Tanzania alongside research,

- Provide a better understanding of how various policy/business models can shape markets for nutritious foods, and how they can achieve sustainability and scale,

- Increase awareness of the risks and unknowns that affect the implementation and outcomes of market-based nutrition programmes,

- Strengthen the use of the evidence on markets and nutrition,

- Inform IDS research strategies during 2015-16 and beyond.

Workshop participants included policymakers, programme managers and practitioners with specific expertise in nutrition, markets and/or business. 


\section{Methods}

The workshop was divided into 3 parts: 1) a presentation of research by the IDS team highlighting lessons and key questions; 2) a hands-on, small group exercise analysing four case studies from Tanzania, led by programme experts; 3 ) a facilitated exercise synthesizing and prioritizing the key challenges across the case studies.

The small group exercise analysing case studies from Tanzania requires further explanation. Each group included 5-8 members and a case study leader who was familiar with the design and implementation of the project (the case study projects are described below). Group members first 'interviewed' the case study leader in order to bring out the key elements of the project and to build a visual representation of its 'impact pathway'. This diagram depicted 3 things: 1) the ultimate food and nutrition objectives of the project, 2) the sequence of intermediary events and outcomes through which the project intended to contribute to this objective and 3) influential actors and processes beyond the immediate control of the project. Participants had freedom to determine the 'nutrition objective' as well as the intermediary events and outcomes ${ }^{1}$.

After completing the diagrams, the small groups rotated using the 'world cafe' approach to view one another's case studies. Through this process, each group received feedback from each other group, including gaps and assumptions in the approach and key questions. This feedback was recorded by facilitators. At the end of the exercise, participants returned to their 'home group' and selected from this feedback 3 key questions, gaps or issues to present back to the plenary session.

The final stage of the workshop involved discussing the key issues identified by each small group, identifying areas of convergence and finally agreeing on 3 overall issues/insights that applied across all of the case studies (these priority issues are detailed in the 'Key Messages' below).

\footnotetext{
${ }^{1}$ Several of the projects aimed to achieve multiple objectives, with nutrition placed alongside strengthening business activity and developing new value chains.
} 


\section{IDS Research Presentation}

The workshop opened with a presentation of research insights by Ewan Robinson, Research Officer at the Institute of Development Studies. The text of this presentation is included below.

\section{What's the problem? Why are we all here today?}

Undernutrition is a big issue, including here in Tanzania. Others in the room today have greater expertise in this area, and can describe the situation in much more detail. Evidence shows that there has been some recent progress, but undernutrition in young children is still extremely prevalent throughout the country, and it has enormous human and economic costs. Undernutrition is also an increasing policy priority, both here in Tanzania and globally. Within nutrition policy, there is an increasing emphasis on the roles of business and markets in delivering nutrient-rich foods. But markets and businesses are extremely broad and diverse; the challenge is to be much more specific about where the greatest opportunities are and how to focus limited resources to achieve the greatest nutrition impacts.

Why do markets matter in food and nutrition? As a starting point, we know that large numbers of people are already buying food from markets. This includes rural households and those involved in farming. While many households produce food for their own consumption, they may depend on markets for certain foods and for certain times of the year. With changes in livelihoods and urbanisation, the reliance on food markets is likely to increase. We know that businesses - both large and small - are increasingly seeing commercial opportunities by meetings these sources of demand. This will be an area of increasing private investment.

But markets and businesses are extremely diverse. There are enormous differences in the incentives, conditions and constraints faced by different actors, from small farmers to traders of agri-commodities, from vendors of fresh fruits, micro-enterprises producing lishe flour, to large-scale food manufacturers. These businesses also function in very different market environments: the challenges faced for the mandatory food fortification program are quite different from the challenges facing businesses that sell fortified products where fortification is not required by law. The same applies for unprocessed foods; traditional foods rich in nutrients - like leafy greens - have challenges around consistent availability, changing consumer tastes and being affordable. Meanwhile, biofortified crops such as orange-fleshed sweet potato face different issues in being introduced as new crops and new foods. Many of the policy discussions tend to lump together 'the private sector' as a single entity. But in fact there is enormous heterogeneity. In order to assess 'the role of business' in nutrition, we need to be much more specific: we need to look at specific markets and sectors - and what kinds of approaches could improve their contribution to nutrition.

The starting point for this analysis is that there is a major problem, and markets are not functioning to deliver nutrition. Although there is lots of business activity in the agri-food sector, the majority is not targeting nutrition. If we could address the nutrition problem simply through entrepreneurs coming up with good ideas for nutrient-rich products and value chains, we would see many more successful businesses in this space - and many more people would have access to these foods. But this is not happening. Based on our research, we believe this situation results from the specific constraints business face in pursuing nutrition activities. Many of these constraints are beyond businesses' immediate control. So there is a need for more systemic action. How do we create an environment - among both policy and business - that promotes business action for nutrition? And where should both public and private sectors focus their limited resources? Do we know what works in marketbased and business approaches to nutrition? 


\section{Major challenges facing markets and nutrition}

From our research, I want to highlight a few big themes that we think are common in many of the specific interventions and businesses we've studied. I want to illustrate this with some specific examples. As I mentioned, we argue that there are big challenges facing markets for nutrition, and these are beyond the control of any individual business. The incentives are not there for action that improves nutrition for the vulnerable groups.

We illustrate these challenges by identifying 4 key nutrition conditions: these are the requirements we must meet in order for a particular food to contribute to better nutrition for the 1,000 days and for low income populations. These conditions are about the food itself and about how it is used and who eats it. They are listed in the Table shown below. But when we are seeking to provide foods through markets, these nutrition conditions also raise a second set of issues, which are specific to businesses. Businesses cannot simply deliver nutrient-rich foods; they need to do it in a way that enables them to earn profits and have a sustainable business model. Businesses in Tanzania face intense competition over prices and operate in a difficult environment. Although businesses have the potential to meet each of the nutrition conditions, this increases their costs, creating challenges to the viability of the business model. As a result, the incentives to businesses are not aligned with what we want in terms of nutrition. The Table below shows the link between the nutrition conditions and the business challenges.

The key observation regarding these business model issues is that they generally cannot be addressed by businesses individually; they reflect underlying market failures and misaligned incentives. As a result, markets are not functioning in a socially optimal way. Addressing them requires interventions and institutions at the market level and the policy level. These challenges will be familiar to practitioners working on markets and nutrition. In fact, many of the existing programmes on food and nutrition are already designed to avoids some of the market problems. For example, think about public distribution systems, such as the UNICEF programme which manages global procurement and distribution of Ready-to-Use Therapeutic Foods (RUTF) targeting children affected by Severe Acute Malnutrition. These public systems avoid the market constraints related to low nutrition awareness and the difficulty of targeting vulnerable groups - the public sector provides products directly to the vulnerable groups for free. Consumers do not need to choose among competing products. Control exerted by public agencies also allows them to impose requirements for quality and nutrient content without the issues of product differentiation or competition from pass-off products. A second example of how programmes work around the business challenges is mandatory fortification. When fortification is universal (for example when all available vegetable oil is adequately fortified), this avoids the constraints of low nutrition awareness and low demand. Again this means that consumers do not need to choose between a fortified and unfortified product; they may not even be aware that a product is fortified.

These are two examples of how the business constraints can be avoided. What strategies and institutions are needed to create these changes on a sustainable basis and in a way that reaches vulnerable groups? What are the key challenges in designing and implementing these strategies? This will be the focus of today's workshop; we will be looking at specific experience here in Tanzania. It's important to look at specific examples because the solutions need to be tailored to specific market environments, even while the issues facing nutrition are more universal. Before we turn to the Tanzania case studies, I want to offer a few more examples from our research that highlight key questions we need to ask about market-based approaches. 


\section{Table 1: The delivery of foods that reduce undernutrition creates specific challenges for business models}

\begin{tabular}{|c|c|}
\hline Conditions for improving nutrition & Business model challenges \\
\hline $\begin{array}{l}\text { 1. Provide nutritional value } \\
\text { Food must contain key micronutrients that } \\
\text { address deficiencies in the population, and } \\
\text { these must be maintained throughout value } \\
\text { chain. }\end{array}$ & $\begin{array}{l}\text { Maintaining nutrient content. Designing a } \\
\text { product with sufficient nutritional value and } \\
\text { then ensuring that this value is maintained } \\
\text { through processing, storage and } \\
\text { distribution. }\end{array}$ \\
\hline $\begin{array}{l}\text { Foods must also be eaten in the right } \\
\text { quantities, and nutrients must be absorbed in } \\
\text { the body. }\end{array}$ & $\begin{array}{l}\text { Correct use of product. Motivating and informing } \\
\text { consumers to use the product in the correct } \\
\text { way (particularly difficult when a food must } \\
\text { be eaten daily to be effective). }\end{array}$ \\
\hline $\begin{array}{l}\text { 2. Reach undernourished people } \\
\text { The food is eaten by the most affected } \\
\text { populations. This can be characterised as an } \\
\text { issue of targeting and coverage. }\end{array}$ & $\begin{array}{l}\text { Availability. Food must be distributed to the } \\
\text { places where the poor can obtain it without } \\
\text { undue difficulty. The extent of availability is } \\
\text { coverage. }\end{array}$ \\
\hline $\begin{array}{l}\text { The most important groups are pregnant and } \\
\text { lactating women and children under the age } \\
\text { of two, often known as the } 1,000 \text { days group. } \\
\text { The poorest groups are also much more } \\
\text { vulnerable to undernutrition. }\end{array}$ & $\begin{array}{l}\text { Affordability. It must be sold at very low prices } \\
\text { that the poor can afford to purchase it } \\
\text { regularly. }\end{array}$ \\
\hline $\begin{array}{l}\text { 3. Ensure consumers value nutrition and } \\
\text { are willing to pay } \\
\text { Potential consumers must value good } \\
\text { nutrition and health, recognize the nutritional } \\
\text { benefits of the food and be willing to pay for } \\
\text { them. Given that food purchases compete } \\
\text { with other uses of scarce incomes, how } \\
\text { consumers recognise and value nutrition } \\
\text { affects affordability. }\end{array}$ & $\begin{array}{l}\text { Nutrition awareness. In business terminology, } \\
\text { nutrition is a "push good": consumers are } \\
\text { unaware of the values it provides. This is a } \\
\text { challenge, since a single business can } \\
\text { rarely capture the value of investments } \\
\text { made to raise awareness. This role is often } \\
\text { played by public education. } \\
\text { Targeting. The food must be promoted in such a } \\
\text { way that it is consumed by the population } \\
\text { groups that most need it. }\end{array}$ \\
\hline & $\begin{array}{l}\text { Consumer preferences. They must also meet } \\
\text { consumer preferences for taste, texture, } \\
\text { packaging and food preparation time. This } \\
\text { is the acceptability issue }\end{array}$ \\
\hline $\begin{array}{l}\text { 4. Assurances of nutritional quality } \\
\text { Consumers must believe claims made about } \\
\text { the benefits of products, especially when } \\
\text { nutrient-rich products are more expensive. }\end{array}$ & $\begin{array}{l}\text { Product differentiation. Businesses need to find } \\
\text { ways to convince consumers that claims } \\
\text { about their products are true and to } \\
\text { distinguish their products from inferior or } \\
\text { fraudulent copies. }\end{array}$ \\
\hline $\begin{array}{l}\text { Achieving this is difficult, because nutrients } \\
\text { are 'invisible', particularly in processed foods } \\
\text { that have been fortified with added nutrients. }\end{array}$ & $\begin{array}{l}\text { Pass-off products. Businesses also need to } \\
\text { protect their businesses against false } \\
\text { claims by competitors, imitations and fakes } \\
\text { These undermine incentives for legitimate } \\
\text { producers and marketers. }\end{array}$ \\
\hline
\end{tabular}

\footnotetext{
2 Dietary factors - such as eating starchy foods with high levels of phytates - and health conditions such as chronic, low-level infections - can severely reduce the body's capacity to absorb micronutrients in foods.
} 


\section{Lessons from real world examples}

Nigeria's fortification programme: Fortification has had nearly ten years of support from key Federal Ministries and development partners in Nigeria, and there has been extensive capacity building for regulatory agencies and food manufacturers. Yet in 2013, an in-depth survey of fortification levels at the retail level found that compliance with the fortification standards was very low, with only 10-30 percent of products compliant (Ogunmoyela et al. 2013). This highlights 2 issues: 1) What incentives exist for businesses to comply? Despite public statements in support of fortification by business leaders, this was not generating committed action at the production level. 2) How do we strengthen the capacity of regulatory bodies? In the case of Nigeria, technical training, provision of equipment and sustained support from partners has not succeeded in enabling regulatory agents to be effective in monitoring and sanctioning businesses. For more information, see (Robinson, Akinyele, et al. 2014).

\section{Business models to deliver fortified complementary food products to low income households. A recent report examined in-depth case studies of 4 business initiatives delivering fortified complementary food in Cote d'Ivoire, Burkina Faso, Madagascar and South Africa (Hystra 2014). The report emphasized that all of these models required very substantial investments in promoting products, increasing consumer awareness and ensuring products were used correctly. This often required door-to-door sales forces who could regularly follow up with customers. In the cases reviewed, this approach was effective in generating demand, but it came at a cost: on average 70 percent of the products' end- price stemmed from product distribution and promotion. These costs are very high, even though the initiatives targeted urban areas, where population is denser and distribution costs are lower per capita.}

Quality and reliability in small enterprises. Ghana has a vibrant local market for complementary food products, primarily mixed cereal-legume flour products produced by small enterprises and distributed within a single market or urban area. These products cost less than $1 / 3$ of the branded alternative. One study sampled a variety of these local products and tested their nutrient content; it found that some of the products were in fact nutritionally adequate for healthy complementary feeding (when used correctly); however, others had very low content of macro- and micronutrients (they were essentially only roasted maize flour). The problem is that there was no way for consumers to know which products were nutritionally adequate and which were not. The market is opaque. This case suggests that there may be potential to produce nutritionally adequate foods locally through a network of small enterprises - but doing so reliably requires the correct incentives. It also highlights the importance of creating mechanisms that can signal nutritional quality. There are a variety of policy options for how public and private sector organizations can do this (for more information, see (Anim-somuah et al. 2013; Masters et al. 2011)).

Reducing aflatoxin in groundnut supplies in Ghana. Aflatoxin is a toxic compound produced by species of fungus that grow on grains, especially maize and groundnuts. Ingesting aflatoxin has been linked to liver cancer in adults and to stunting in children. A USAID-funded research and product development programme sought to reduce aflatoxin in value chains for groundnuts in Ghana. However, it struggled to create incentives for actors 'upstream' in the value chain: especially farmers and commodity traders. Improved agronomic and storage practices could reduce growth of the fungus and prevent aflatoxin contamination. However, traders did not offer farmers a price premium for properly-stored groundnuts, and thus they did not adopt better practices. Because of these challenges, the preferred method for reducing aflatoxin in the value chain was to sort groundnuts at the stage of food processing or retail. However, this created its own problems. The contaminated groundnuts that were removed during sorting were not discarded; they were resold at a lower price. As a result, they tended to be steered towards poor consumers, increasing their health risks. This highlights that markets are linked: the formal sector businesses that partnered with the project were producing "aflatoxin-free" products (sold at a 
higher price). But these businesses were linked to informal market that sold contaminated supply (at a lower price). Solving a problem in one market can create a problem in another. Policy solutions need to look across both formal and informal markets, rather than focusing only on individual businesses.

\section{Factors not discussed today}

Before leaving you with some of the issues I think you should consider in today's workshop, l'd like to acknowledge what I have left out in considering ways to improve nutrition:

- Ways to improve nutrition for people involved value chains through the non-food drivers of nutrition, such as when employers provide key health services to employees.

- Behaviour change approaches targeting key nutrition actions, including through local health workers, social marketing, text messaging, etc.

- Increasing households' incomes - and the distribution of income and decision making within households - accompanied by promoting the use of income for better nutrition, for example linking farmers to value chains paired with nutrition education and health services.

These approaches are also vitally important. We know nutrition requires action in different sectors and drivers. Our research has focused on the availability and accessibility of food because we think there are important common challenges and responses when looking at food markets.

\section{Key questions for market-based initiatives}

What are the implications of our research and the examples highlighted above for marketbased initiatives targeting nutrition in Tanzania? First, we think it's important to look more broadly than just the specific activities and formal partners involved in a project. What are the assumptions about how various actors (both public and private) will behave? What are the assumptions about how markets function, and will they continue to function this way in the future? For example: if a project is conducting training for small businesses, what other conditions need to be in place in order for businesses to have the capacity to act on this training? Do they have incentives to adopt better practices on an ongoing basis, within a competitive environment? We want to encourage stakeholders to step back and consider the broader 'market system' beyond individual projects or partnerships. This includes the informal businesses and micro-enterprises that are difficult to reach. It includes legislation and guidelines, as well as how these guidelines are implemented (or not) by actors at the local level. I leave you with 5 key themes to refer to as you analyse the experience in Tanzania during today's workshop:

1. Incentives and market conditions. What are the motivations and incentives driving business action? How do market conditions affect these incentives?

2. Diversity of markets. There are different kinds of markets, including formal and informal, national and local scale. These markets are often interlinked; as we saw in the aflatoxin example. Consider the market in which an individual product is sold. How do they interact with other products? What are the value chains from which key populations and income groups purchase products at present?

3. Sustainability and stability. If an intervention or business model depends on current market conditions (or policy conditions), what would happen if these conditions changed in the future? For example, if an initiative is selling a micronutrient powder product (MNP), are there currently any competing products? What would happen if a competing 
product entered the market, or was imported? Would the genuine product be competitive? If a product depends on strict regulation to control pass-off products, how likely is it that this level of enforcement can be maintained?

4. Capacity of both public and private institutions. We have seen that the capacity of regulatory agencies and staff to undertake monitoring and enforcement can be a huge problem for fortification programmes. What would strong institutional capacity look like? Are training and equipment adequate to enable regulators to be effective and consistent? What kinds of capacity are needed by private businesses (to interact with public agencies, to implement technical requirements, to interact with consumers)?

5. Evidence. What evidence do we use when we design and implement market-based programmes? Much of the existing evidence base refers to programmes and products under carefully controlled pilot or trial conditions. But market-based approaches are inherently difficult to control and to predict in the long term. Do we have evidence about what works under real world conditions and in real markets? What do we need to know? Given the difficulty and cost of conducting full-scale trials and experiments, how can we measure the success of programmes?

I have emphasized that the challenges and solutions are only meaningful in specific contexts. Improving our knowledge about how to strengthen markets and where the key opportunities lie means engaging with those who have in-depth implementation experience. We are very keen to learn from your knowledge and experience. We hope the ideas from today will be useful in thinking about your own programmes, policy and advocacy work. We're eager to hear at the end of the day how we can take this forward and support your efforts, and how research can contribute. Thank you very much for your participation. 


\section{Tanzania Case Studies}

Expert case study leaders presented 4 case studies of programmes and initiatives aiming to increase access to nutrient-rich foods in Tanzania using market-based approaches. Small groups then worked with the case study experts to develop a shared analysis of each project, and to produce visual representations of the causal logic ('impact pathway') through which it contributes to reducing undernutrition (these diagrams can be found in Annex C). Each of the case studies is introduced below, followed by the key findings from analysis.

\begin{tabular}{|l|l|l|}
\hline Case Study & Leader & Affiliation \\
\hline Universal Salt lodization & Dr. Vincent Assey & $\begin{array}{l}\text { Ministry of Health and Social } \\
\text { Welfare }\end{array}$ \\
\hline $\begin{array}{l}\text { Development of new } \\
\text { products using OFSP } \\
\text { (via SUGECO) }\end{array}$ & Prof. Anna Temu & $\begin{array}{l}\text { Sokoine University of } \\
\text { Agriculture }\end{array}$ \\
\hline $\begin{array}{l}\text { Rural Food Fortification } \\
\text { Program }\end{array}$ & Mr. John Mwingira & $\begin{array}{l}\text { Tanzania Food and Drug } \\
\text { Authority }\end{array}$ \\
\hline Tuboreshe Chakula Project & Ms. Rebecca Savoie & Tuboreshe Chakula Project \\
\hline
\end{tabular}




\section{Group A: Universal Salt Iodization}

Salt iodization (fortification with iodine) has been mandatory in mainland Tanzania since 1995, and a number of programs funded by government and development partners have supported implementation and extended its reach. Government and UNICEF have been especially active. There has been considerable progress in ensuring a greater proportion of people and households have access to iodized salt. However, coverage remains limited especially among SMEs - due to weak enforcement of the regulations.

\section{Activities}

- Training of salt producers in iodization procedures and quality assurance.

- Small producers were given simple, hand-held spray pumps and received training. These pumps cost much less than conventional iodization equipment.

- Tanzania Salt Producers Association created a revolving fund in 1999 to ensure that its members would have a regular supply of potassium iodate (the ingredient used in iodization).

- TFNC has promoted consumer demand for iodized salt.

- Government has establish testing laboratories in remote areas and provided rapid testing kits.

- lodized salt was included in Monitoring and Evaluation Framework for fortified products.

\section{Outcomes so far}

Tanzania maintained over $80 \%$ coverage with iodized salt over the past 10 years. However, iodine content is inadequate in eight regions where small-scale salt production is practiced, including Lindi (5\% coverage) and Mtwara (23.4\%). In the most IDD affected areas in Tanzania, total goitre prevalence (TGP) dropped from 65\% in 1980 s to $24 \%$ in 1999 .

\section{Challenges encountered}

- Problems with equipment. Small-scale producers use improvised equipment that is not reliable. This leads to wide variation in iodization levels, with 24-69 percent of samples either under- or over-iodated.

- Affordability. Improved manual sprayers and potassium iodate supplies are still not affordable for small salt producers on a reliable basis.

- Inadequate monitoring and enforcement. Enforcement is particularly weak among SMEs, many of which do not iodate (or do so at inadequate levels). Testing labs are not adequately used, related to weak enforcement.

- Low capacity for enforcement. At district and community level, there are inadequate staff, training and funds for enforcement agents and managers.

- Problems with business revolving fund. In 2010, the global price of potassium iodate skyrocketed. This caused the Salt Producers Association revolving fund to erode. In response, the government donated $8000 \mathrm{~kg}$ of potassium iodate to keep the revolving fund operational.

- Sustainability. Need to shift from donor dependency to mobilise government's own resources in order to fund regulatory system, as well as to fund support services for salt producers. 
Group B: Developing New Products using Orange Fleshed Sweet Potato via SUGECO

The Sokoine University Graduates ECO (SUGECO) has been working on increasing the number of products that can be made using orange fleshed sweet potatoes (OFSP), a sweet potatoes variety which supplies high levels of vitamin $A$, as essential vitamin for immune function and eye health. However, many farmers favour growing the traditional, but less nutritious white fleshed sweet potatoes. SUGECO aims to encourage farmers to grow more of the nutrient rich potatoes by increasing the market for OFSP by creating new products that can be made from OFSP (examples include juice, flour, bread, cookies), building markets for small scale farmers, and promoting development of agribusiness enterprises. The idea is that farmers will adopt and product OFSP only if they are assured of a market will high prices. Developing new businesses and products is a way of growing this market.

(Source: Waized et al, forthcoming)

\section{Activities so far}

- Establishment of Product development lab at SUA. This is exploring ways of making more products with nutrient rich sweet potatoes. So far products include breads, biscuits, juice, and flour.

- Developed contracts with farmers who produce OFSP to provide a guaranteed market and incentive growing OFSP.

- SUA research group on agribusiness management, entrepreneurship and Innovation

- SUGECO supported by SUA to stimulate business development in agricultural/ agribusiness sector through business incubation model

- Involvement of local government ready to adopt business incubation model

Challenges Encountered:

- Public awareness of OFSP, especially in urban areas as education efforts are targeted at rural areas and people are unwilling to pay more for OFSP (which farmers expect, thus traders who sell to urban markets do not purchase)

- Production is still too small scale to guarantee markets for large scale industrial production.

- Value chain interventions are fragmented and lack links with other value chains.

- High cost of getting new products certified, especially for small scale producers.

- Users of products (such as bakers) have specific expectations (e.g. using only dry ingredients) that restrict the range of products (e.g. nutrient-dense OFSP mash).

- Tanzanian agricultural policy does not include roots and tubers; only maize is subsidized.

- Lack of national repository for information about product development.

- Donor interventions and funded research tend to prioritize very small scale and poorest farming households.

\section{Indicators used to measure success}

- Publications in academic circles

- On the ground products include use of OFSP in various food products, possible enterprise development on the value chain,

- Demand for planting material started thus kick-started adoption

- Various product with OFSP awaiting PBS certification.

- Increased consumption of nutrient rich foods, including OFSP but efforts need to think more broadly than one crop and focus on increasing nutrient consumption through increased dietary diversity. 


\section{Group C: Rural Food Fortification}

The Rural Food Fortification program aims provide micronutrients to rural populations. It encourages small-scale maize flour millers to fortify their products and encourages households to fortify foods at home. Small millers are a key target because they process the overwhelming majority of maize flour eaten in Tanzania. Although fortification of maize flour is required by the National Fortification Program, almost no small millers currently use fortification. The Program is working in 6 districts (Iringa rural, Kilolo, Karatu, Meru, Monduli and Njombe town council), where there are often 1-5 millers per village. The project is coordinated by the MoHSW, working with TFDA, TFNC and Prime Minister Office Regional Administrative and Local Government (PMO-RALG). It was funded by the World Bank and JICA. The program timeframe is 2 years.

\section{Activities so far}

- Collected baseline data. Informed decision makers in the districts.

- Developed simplified training manuals and guidelines.

- Developed social marketing materials, including radio/TV spots and text messaging.

- MoHSW trained nutrition project officers on essential nutrition actions and fortification.

- TFDA trained food safety inspectors and hammer mill operators.

- MoHSW procured processing equipment and lab testing materials.

- Provided millers with 'pre-blend' which is diluted to an appropriate concentration for smallscale fortification and basic equipment.

- TFDA is responsible for monitoring fortified foods.

\section{Outcomes so far}

Decision makers and officials in the project area have expressed support for the programme, and millers have stated they are willing to begin fortification. Community members have also expressed willingness.

\section{Challenges encountered}

- Small millers often do not use good hygiene and quality assurance practices; they may lack proper facilities. They do not comply with TFDA requirements.

- Staff turnover is very high for small operators, which can limit the effects of training when the staff who have been trained leave.

- The system for distributing the fortificants in rural areas is inefficient.

- There is a lack of Rapid test Kits that local inspectors can use to check product quality.

- It is unclear whether the supply of fortificants will be sustained after the project funding period ends.

- Longer term, it may be difficult for TFDA to have sufficient budget to maintain contact with the small enterprises.

\section{Indicators used to assess the project}

- ${ }^{3}$ Micronutrient content in fortified food and Micronutrient powder

- ${ }^{1}$ Total quantity of fortified flour

- $\quad{ }^{1}$ Degree of conformity of fortified maize flour with fortification standards

- ${ }^{1}$ Prevalence of households that have fortified flour

- ${ }^{1}$ Average quantity of fortified flour consumed per household per day

- ${ }^{4}$ Prevalence of iron deficiency anaemia in women of child bearing age

- ${ }^{2}$ Prevalence of folate sufficiency in in women of child bearing age

- ${ }^{2}$ Birth prevalence of neural tube defect

\footnotetext{
${ }^{3}$ Indicator of direct project outcomes.

${ }^{4}$ Indicator of ultimate impact.
} 


\section{Group D: Tuboreshe Chakula}

Initiated in 2011, Tuboreshe Chakula is a $\$ 22$ million USAID-funded project aiming to enhance the competitiveness of food processors and to encourage them to fortify products with micronutrients, as well as to increase consumer demand for fortified foods. It has worked with 733 small and medium food processing businesses across 3 regions (Dodoma, Manyara, Morogoro). These include processors of maize flour and sunflower oil. The project has been one of the first in Tanzania aiming to build the capacity of SMEs for fortification and to generate market incentives. A second component of the project helped create a market via various distribution channels for micronutrient powders, which are used by households fortify foods in the home ${ }^{5}$. By its close in June 2015, the project will have created commercial channels for all 5 products.

\section{Activities}

- Provided training and business support including business plans, good manufacturing practices, quality assurance processes, and marketing strategies.

- Helped businesses improve supply chain management, including connections with another Feed the Future project that works with farmer groups.

- Worked with a range of financial institutions to facilitate access to finance for food processors.

- Established a supply of fortification equipment for small maize mills by partnering with a private tech provider.

- Sponsored behaviour change campaigns on nutrition and fortification, including radio.

- Facilitated approval and importation of MNP product. Tested distribution models with several firms to distributeto village shops \& kiosks which sell to consumers. .

\section{Outcomes so far}

- 30 percent increase in number of families with young children using MNP.

- 60 percent of project -assisted businesses are operating more profitably.

- Grants totalling \$1.5 million have been awarded to flour processors.

- Largest maize miller fortifies 30 MT flour per day, enough for 150,000 individuals.

- 50 businesses have acquired dossifier equipment for fortification.

\section{Challenges encountered}

- Training the right staff in small enterprises was another challenge, reducing the impact of project training.

- Lack of incentives. Currently SMEs had few incentives to fortify products, because of lack of clarity about enforcement and low demand for fortified products.

- Business registration requirements: As of early 2014, the project faced difficulties getting SME food processors to introduce fortification. One issue was that government agencies require businesses to officially register before being allowed to fortify. Most SMEs were not able to meet the registration and certification requirements. As a result, only 15 of the participating maize millers had successfully registered with BRELA in 2014.

- Misconceptions. Some rural residents are suspicious of MNP products, despite sensitization campaigns. They may associate MNP with birth control and infertility, or believe it is intended only for severely malnourished children.

- Building distribution and retail. Large private distributors not interested in demand creation for new products. High cost of distributing to rural areas and monitoring retailers' behaviour.

\footnotetext{
5 this component also includes Zanzibar
} 
- Need for better regulatory environment, including coordination/harmonization of formulation, standards, labeling, tax exemption, registration and promotion.

- Reaching the poorest. The project has encountered constraints in reaching the poorest groups through markets. Even very low cost products such as MNP are not affordable to the poorest on a consistent basis. There is a need for parallel programmes such as social protection to improve nutrition for the poorest.

\section{Key Lessons}

The groups analysed each of the case studies and identified three lessons from each case study that could be useful for improving other market-based nutrition initiatives and creating a supportive policy environment. In total, 9 key lessons were identified. Three of these lessons resonated with more than one of the case studies; these were selected by participants as the most important cross-cutting themes of the workshop:

1. There is a need for new and more effective processes and structures for enforcement. Enforcement was a major challenge facing several of the case studies. Participants pointed out that public trust regarding product claims and standards was very low. This applies even in the case of the national fortification programme; there are doubts whether the fortification logo (e.g. on wheat flour) accurately reflects whether the product is truly fortified. Other participants pointed out that enforcement has been uneven among small and medium enterprises. One project cited the experience of maize millers; only certain millers have received letters from regulators instructing them to fortify. Others have not received a letter, raising doubts about fair and even enforcement. The Tuboreshe Chakula case highlighted that the need to comply with legal requirements and the threat of sanctions was a key motivation for millers to fortify.

The workshop concluded that the current system of enforcement was not effective or consistent at the local level. Participants asked how the capacity and effectiveness of the system could be strengthened and whether current efforts were sufficient. Some participants were eager to learn from experiences in other countries and in other sectors, particularly regarding how to motivate compliance with standards in markets with a strong presence of micro- and small enterprises. Several participants suggested that enforcement should not be seen as simply a matter of public agencies monitoring and sanctioning businesses based on their compliance; instead sanctions needed to be accompanied by positive incentives for businesses. For example, Tuboreshe Chakula motivated small businesses to adopt food safety practices by providing business development services that also improved efficiency and reduced costs. Workshop participants proposed that enforcement should be seen as part of a broader issue of 'market governance' for nutrition.

2. Public awareness and trust (particularly in processed foods) is needed at the national scale, beyond the direct influence of particular projects. Several of the case study projects had encountered strong public skepticism about the safety, purpose and meaning of fortified products. People were especially skeptical of new, processed foods and those that were seen to be supported by outside development partners. Projects had invested substantial resources to deliver messages that these products were safe and contributed to healthy development of children. But with limited resources and public legitimacy, projects could not change these perceptions at the national level and on a sustainable basis.

Some participants suggested that there was a need for prominent public figures, including politicians, to make public statements in support of fortified products. Similar challenges were also encountered when promoting other new product types (such as processed foods derived from fruit and vegetables). Workshop participants 
wanted more information about what models are effective in changing public perceptions and increasing nutrition awareness at large scale. Some participants proposed public-private partnerships in which public sector institutions provide nutrition awareness messages and coordinate them with the product promotion and advertising of private companies. Participants wanted to learn from real-world experience with these models to assess their effectiveness and how to design and implement them.

3. There is a need for better structures for coordinating programmes that involve multiple actors and different sectors (public/private/CSO). All of the case studies involved coordinating a large number of actors across different sectors, with different roles and motivations. This was contrasted with interventions that have more linear lines of accountability and responsibility within a single ministry or business. Case study initiatives had faced challenges in ensuring that all actors played their roles effectively and consistently. It was especially difficult to ensure that particular organisations (or managers) were ultimately responsible for the delivery of programme objectives. This was difficult not only across sectors, but among different partner organisations within a sector (e.g. across relevant Ministries and agencies). Participants wanted to know what institutional structures for project coordination have been effective in other countries and contexts (several examples were offered of approaches used in neighbouring countries). Several participants were interested in how to hold the various actors accountable for outcomes.

In addition to the 3 cross-cutting themes just described, the workshop identified a further 6 priority issues and lessons for market-based approaches:

4. How to measure the success of initiatives that have both business and nutrition objectives? Market-based nutrition interventions inherently require multiple objectives: they must both increase access to foods that contribute to better nutrition, while also ensuring these activities are viable and sustainable in a business environment. For example, the Tuboreshe Chakula project is modeled as a 'business development project with nutrition outcomes'. It is accountable for improving the commercial performance of the SMEs it targets, as well as contributing to nutrition by making fortified products available. The use of multiple objectives creates a challenge for project evaluation and accountability. What outcomes are projects ultimately responsible for, given that they must work with other actors that are beyond the project's immediate control? Projects also face constraints in which processes and outcomes they can measure and at what level of detail and rigor. It was noted that measuring outcomes in terms of nutrition indicators was the gold standard, but is extremely expensive.

5. How can projects plan for the sustainability of their activities? All of the case study initiatives intended to trigger changes in the behaviours of businesses and the performance of markets that would be sustained beyond the timeframe of the project. Experience from past initiatives (particularly the Universal Salt lodization programme) suggested two key challenges: 1) existing institutions may not have the resources or incentives to continue to play their role (e.g. enforcement or training by public agencies) and 2) businesses may not have incentives to continue activities (e.g. continued fortification) after project support ends. The Tuboreshe Chakula project has aimed to work with existing private sector providers with the intent that they will continue to deliver services and equipment to businesses after the project ends. It is too soon to assess whether these providers will continue to play this role.

6. Low cost technologies can have high potential for increasing coverage of nutrient-rich products. Although sophisticated technologies can ensure that products meet precise technical standards for nutrient content or manufacturing 
processes, they are often not feasible for micro- and small-enterprises. There may also be problems in ensuring a reliable supply of sophisticated technologies and technical expertise. The Universal Salt lodization programme had seen considerable success with small enterprises adopting fortification through adapting and disseminating simple pumps for adding iodine to salt at small scale. Participants suggested that other products and sectors might also benefit from simple and adaptable technologies.

7. Projects encounter major difficulties and expense when working with small enterprises. Several projects reported that working with micro- and small-scale enterprises was difficult, time-consuming and expensive. Small enterprises often begin with very limited capacity; projects had spent considerable resources to help them develop better management skills and processes and to introduce quality assurance procedures. Another key challenge were that small enterprises face high levels of staff turnover, or indeed the business itself may cease to exist. Resources invested in training staff and building business capacity can thus be lost. Some case study projects reported that investments were first needed to improve the viability of participating businesses before investing in nutrition activities.

8. There is a need to improve institutional capacity at the level of agricultural production. Developing a better supply of agri-food inputs for nutrient-rich products requires investing in agricultural production and marketing systems. The case of SUGECO suggested that under the right conditions, food processors could establish purchasing contracts with farmers that were mutually beneficial. However, current efforts to promote nutrition through agriculture are neglecting these activities, and focusing instead on promoting nutrient-rich crops for consumption within producer households. The case of OFSP suggests that farmers are more likely to adopt a crop (even a food crop) when there are viable markets. Developing these markets will require investing in farming and marketing systems.

9. The current regulations regarding business registration, food safety and fortification are too complex for SMEs. Participants widely agreed that current regulations, including business registration requirements and the food fortification legislation, make it difficult for small and medium enterprises to introduce improved practices such as fortification. The regulatory environment and regulators' orientation towards policing (rather than facilitating compliance) also discourages SMEs from engaging with projects and public agencies and inhibit uptake of training and capacity building. Participants specifically identified the need to define how the fortification policy applies to SMEs, which is lacking in the current legislation. 


\section{Next Steps and Opportunities}

In the final session of the day, participants were asked to reflect on how they were going to move priority agenda items forward. Specifically, they were asked to reflect on how these lessons could be shared and key changes advocated for in ongoing policy processes in Tanzania. Participants were asked to reflect on the following questions:

- How do the issues and priorities identified today feed into bigger issues?

- How do we go further?

- How can we support this engagement as a research organization?

Prior to the workshop, key stakeholders suggested the following set of meetings as a starting point for discussing next steps and opportunities. These suggestions are listed below, along with actions that can be taken to bring out the findings of this workshop and entry points for discussion and advocacy for key recommendations.

\section{SUN Lead Group meeting 9-10 April}

This is a Global meeting of the SUN lead group, with participants not just limited to Tanzania. It was felt that this would be a good opportunity to share the report more widely with a global audience of stakeholders.

\section{Stakeholders meeting on food fortification in Tanzania - 22 April}

One of the meeting participants, Rebecca Savoie, Chief of Party for the Tuboreshe Chakula programme is in charge of organizing this meeting. She offered to bring the findings from this workshop to that meeting, and offered and open invitation to other participants of the day to contact her should they wish to also attend the meeting and share findings from the day's workshop. The findings from this workshop would help to develop the key messages that Tanzania will bring to the Global Summit on food fortification (see below).

\section{FANUS conference - 22 - 29 May}

Given the academic nature of the programme and short time frame, participants agreed this was not a priority for sharing workshop findings.

\section{Review of national nutrition strategy implementation - end Aug}

While the national nutrition strategy does not specifically deal with the private sector, the review meeting might present an opportunity to discuss specific issues around fortification.

\section{Global Summit on Food fortification $-2^{\text {nd }}$ week September (TBC)}

Participants suggested that Tanzania's contribution to this meeting could be informed by the outcomes of the workshop. Input can be fed through the skakeholder meeting on food fortification in Tanzania (22 April).

Participants felt that, while these meetings were a starting point, there is a need to identify other key fora and organisations to target with policy recommendations. Participants agreed that they would seek to identify entry points for sharing messages.

Several organisations suggested the workshop would be able to inform their efforts to develop strategies for action and engagement. PANITA is currently developing a strategy for 2015-19, including outlining the network's approach to engaging with the private sector and identifying a role for network members in addressing priority issues in market-based programmes, particularly nutritional awareness at the community level. In addition, the SUN Business Network is presently scaling up its efforts in Tanzania and contributing to a national roadmap on food fortification. Tanzania network manager Enock Musinguzi indicated that the lessons and gaps identified in the workshop could feature in the network's longer-term 
strategy. PANITA and the SUN Business Network agreed to pursue a follow-up meeting to discuss the roles and cooperation among the two networks.

\section{Research Priorities}

One channel through which the workshop aims to strengthen policies and programme is by pursuing strategic research topics that are of high priority for stakeholders. By incorporating these priorities as part of ongoing research on business, markets and nutrition during 201516 , the IDS team will aim to provide timely, relevant and demand-driven evidence, analysis and recommendations.

The workshop contributed to the identification of the following priority areas for research:

- Effective approaches for working with small enterprises and informal markets. All of the initiatives examined in the case studies encountered substantial challenges in working with and influencing the behaviour of the small enterprises that tend to provide products to poor populations. There is a need to identify interventions and policies that are effective in these contexts. Key insights from the workshop include the potential of low cost technology, as well as the need for broad-based business development services. IDS will pursue this topic through a review of documented experiences in food markets and other sectors, which will also draw on the workshop case studies. IDS will publish this review during 2015 and disseminate it widely.

- Intervening in markets where regulatory capacity is low. Workshop participants underlined that both public agencies and private businesses face capacity constraints that prevent effective implementation and enforcement of standards including food safety and nutrition. It is clear that strengthening institutional capacity will continue to be a focus for Government and development partners, but it is unlikely that capacity will be adequate for the foreseeable future. Research can identify how market-based initiatives can be specifically designed to work around low capacity. IDS research has already explored the potential of private certification schemes (Anim-somuah et al. 2013). Ongoing research will derive lessons for public agencies, funders and implementers based on experience in other sectors, including mobilising the potential of local institutions in monitoring.

- Implementing programmes in complex market systems. A number of the case studies highlighted that working on markets and nutrition requires complex multi-sectoral relationships and the pursuit of multiple objectives (both business- and nutrition-related). In these arrangements, no single actor can control the dynamics of the market system as a whole. This poses a major challenge for development partners and government institutions, which tend to be risk averse and to prefer simple, linear models of intervention. How can development institutions work in complex market systems in order to improve nutrition? How can programmes incorporate and be accountable for both nutrition and market objectives? IDS is drawing on cutting-edge thinking in market systems approaches, including through the work of the IDS Business and Development Centre. This work will contribute to awareness and capabilities of stakeholders in food and nutrition sector to engage with market systems approaches. 


\section{Annex A: List of Participants}

\begin{tabular}{|c|c|c|c|}
\hline Name & Organisation & Position & Email \\
\hline $\begin{array}{l}\text { Ms. Timah } \\
\text { Twalipo }\end{array}$ & $\begin{array}{l}\text { Catholic Relief Services } \\
\text { Tanzania }\end{array}$ & Director of Health Programs & $\underline{\text { Timahabdullah.twalipo }}$ \\
\hline $\begin{array}{l}\text { Mr. Enock } \\
\text { Musinguzi }\end{array}$ & $\begin{array}{l}\text { Global Alliance for } \\
\text { Improved Nutrition }\end{array}$ & $\begin{array}{l}\text { Country Manager SUN } \\
\text { Business Network }\end{array}$ & $\begin{array}{l}\text { emusinguzi@gainhealt } \\
\text { h.org }\end{array}$ \\
\hline $\begin{array}{l}\text { Ms. Joan } \\
\text { Kimirei }\end{array}$ & $\begin{array}{l}\text { Global Alliance for } \\
\text { Improved Nutrition }\end{array}$ & $\begin{array}{l}\text { Manager- Marketplace for } \\
\text { Nutritious Food }\end{array}$ & ¡kimire@gainhealth.org \\
\hline $\begin{array}{l}\text { Mr. George } \\
\text { Kaishozi }\end{array}$ & $\begin{array}{l}\text { Helen Keller } \\
\text { International }\end{array}$ & Fortification Coordinator & gkaishozi@hki.org \\
\hline $\begin{array}{l}\text { Dr. Subilanga } \\
\text { Kazimoto }\end{array}$ & $\begin{array}{l}\text { Ministry of Health and } \\
\text { Social Welfare }\end{array}$ & Medical Doctor / Nutritionist & skazimoto@yahoo.com \\
\hline $\begin{array}{l}\text { Ms. Grace R. } \\
\text { Moshi }\end{array}$ & $\begin{array}{l}\text { Ministry of Health and } \\
\text { Social Welfare }\end{array}$ & Nutritionist & gmoshy2000@gmail.com \\
\hline $\begin{array}{l}\text { Mr. Vincent } \\
\text { Assey }\end{array}$ & $\begin{array}{l}\text { Ministry of Health and } \\
\text { Social Welfare / TFNC }\end{array}$ & $\begin{array}{l}\text { Assistant Director, Nutrition } \\
\text { Services }\end{array}$ & vdassey@gmail.com \\
\hline $\begin{array}{l}\text { Mr. Tumaini } \\
\text { Mikindo }\end{array}$ & PANITA & Executive Director & $\begin{array}{l}\text { tumainii.mikindo@panita } \\
\text { co.tz }\end{array}$ \\
\hline $\begin{array}{l}\text { Dr. Betty } \\
\text { Waized }\end{array}$ & $\begin{array}{l}\text { Sokoine University of } \\
\text { Agriculture }\end{array}$ & $\begin{array}{l}\text { Dept. of Agriculture } \\
\text { Economics and } \\
\text { Agribusiness }\end{array}$ & yzbetty@suanet.ac.tz \\
\hline $\begin{array}{l}\text { Dr. Daniel W. } \\
\text { Ndyetabula }\end{array}$ & $\begin{array}{l}\text { Sokoine University of } \\
\text { Agriculture }\end{array}$ & $\begin{array}{l}\text { Dept. of Agriculture } \\
\text { Economics and } \\
\text { Agribusiness }\end{array}$ & dwn@business.aau.dk \\
\hline $\begin{array}{l}\text { Dr. Richard } \\
\text { Mongi }\end{array}$ & $\begin{array}{l}\text { Sokoine University of } \\
\text { Agriculture }\end{array}$ & $\begin{array}{l}\text { Department of Food } \\
\text { Science and Technology }\end{array}$ & 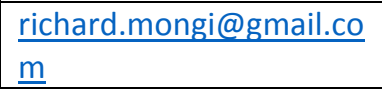 \\
\hline $\begin{array}{l}\text { Mr. John } \\
\text { Msuya }\end{array}$ & $\begin{array}{l}\text { Sokoine University of } \\
\text { Agriculture }\end{array}$ & $\begin{array}{l}\text { Department of Food } \\
\text { Science and Technology }\end{array}$ & j msuya@yahoo.com \\
\hline $\begin{array}{l}\text { Prof. Anna } \\
\text { Temu }\end{array}$ & $\begin{array}{l}\text { Sokoine University of } \\
\text { Agriculture }\end{array}$ & $\begin{array}{l}\text { Dept. of Agriculture } \\
\text { Economics and } \\
\text { Agribusiness }\end{array}$ & $\begin{array}{l}\text { aatemu2002@yahoo.c } \\
\text { o.uk }\end{array}$ \\
\hline $\begin{array}{l}\text { Prof. Peter } \\
\text { Mamiro }\end{array}$ & $\begin{array}{l}\text { Sokoine University of } \\
\text { Agriculture }\end{array}$ & Professor & \\
\hline $\begin{array}{l}\text { Ms.Dorothy } \\
\text { Magesse }\end{array}$ & $\begin{array}{l}\text { Tanzania Agriculture } \\
\text { Productivity Program }\end{array}$ & Nutrition Advisor & dmagesse@fintra.com \\
\hline $\begin{array}{l}\text { Mr.John } \\
\text { Mwingira }\end{array}$ & $\begin{array}{l}\text { Tanzania Food and } \\
\text { Drug Authority }\end{array}$ & $\begin{array}{l}\text { Food Fortification Focal } \\
\text { Person }\end{array}$ & $\begin{array}{l}\text { mwingira77@yahoo.co } \\
\text { m; } \\
\text { john.mwingira.@tfda.or } \\
\text {.tz }\end{array}$ \\
\hline $\begin{array}{l}\text { Dr. Celestine } \\
\text { Mgoba }\end{array}$ & $\begin{array}{l}\text { Tanzania Food and } \\
\text { Nutrition Center }\end{array}$ & Senior Researcher & acelestingoba@yahoo.co \\
\hline $\begin{array}{l}\text { Mr. Laurent } \\
\text { Mselle }\end{array}$ & $\begin{array}{l}\text { Tanzania Food and } \\
\text { Nutrition Center }\end{array}$ & Senior Nutritionist & $\begin{array}{l}\text { laurentmselle@yahoo.co } \\
\underline{m}\end{array}$ \\
\hline $\begin{array}{l}\text { Ms. Lawrencia } \\
\text { James }\end{array}$ & $\begin{array}{l}\text { Tanzania Horticultural } \\
\text { Association }\end{array}$ & $\begin{array}{l}\text { Gender and Nutrition } \\
\text { Specialist }\end{array}$ & $\begin{array}{l}\text { lawrencia.james@tanzan } \\
\text { iahorticulture.com }\end{array}$ \\
\hline $\begin{array}{l}\text { Mr. Joseph } \\
\text { Kayinga }\end{array}$ & $\begin{array}{l}\text { Tanzania Social } \\
\text { Workers Association }\end{array}$ & Publicity Specialist & kayingai@gmail.com \\
\hline $\begin{array}{l}\text { Dr. Elifatio E. } \\
\text { Towo }\end{array}$ & TFNC & $\begin{array}{l}\text { Director Food Science and } \\
\text { Nutrition }\end{array}$ & eetowo@hotmail.com \\
\hline $\begin{array}{l}\text { Ms. Rebecca } \\
\text { Savoie }\end{array}$ & $\begin{array}{l}\text { Tuboreshe Chakula } \\
\text { Project }\end{array}$ & Chief of Party & $\begin{array}{l}\text { rebeca.savoie@tuboresh } \\
\text { e.com }\end{array}$ \\
\hline
\end{tabular}




\begin{tabular}{|c|c|c|c|}
\hline Name & Organisation & Position & Email \\
\hline Joyce Ngegba & UNREACH & UN REACH Coordinator & joyce.ngegba@wfp.org \\
\hline $\begin{array}{l}\text { Ms. Janeth } \\
\text { Said }\end{array}$ & USAID/Tanzania & Nutrition Advisor & jsaid@usaid.gov \\
\hline $\begin{array}{l}\text { Dr. Yahya } \\
\text { Ipuge }\end{array}$ & World Bank Tanzania & Senior Health Specialist & yipuge@worldbank.org \\
\hline $\begin{array}{l}\text { Mr. Masala } \\
\text { Makwassa }\end{array}$ & World Food Program & Senior Program Assistant & $\begin{array}{l}\text { massala.makwassa@wfp. } \\
\text { org }\end{array}$ \\
\hline $\begin{array}{l}\text { Mr. Rogers } \\
\text { Wanyama }\end{array}$ & World Food Program & $\begin{array}{l}\text { Programme Officer- } \\
\text { Nutrition }\end{array}$ & $\begin{array}{l}\text { rogers.wanyama@wfp. } \\
\text { org }\end{array}$ \\
\hline $\begin{array}{l}\text { Willbroad } \\
\text { Karugaba }\end{array}$ & World Food Program & Program Officer & $\begin{array}{l}\text { willbroad.karugaba@wfp } \\
\text { org }\end{array}$ \\
\hline \multicolumn{4}{|c|}{ FACILITATORS } \\
\hline $\begin{array}{l}\text { Ewan } \\
\text { Robinson }\end{array}$ & $\begin{array}{l}\text { Institute of Development } \\
\text { Studies (IDS) }\end{array}$ & Research Officer & e.robinson@ids.ac.uk \\
\hline Kat Pittore & $\begin{array}{l}\text { Institute of Development } \\
\text { Studies (IDS), UK }\end{array}$ & Nutrition Convenor & k.pittore@ids.ac.uk \\
\hline $\begin{array}{l}\text { Prof. Andrew } \\
\text { Temu }\end{array}$ & $\begin{array}{l}\text { Sokoine University of } \\
\text { Agriculture }\end{array}$ & $\begin{array}{l}\text { Dept. of Agriculture } \\
\text { Economics and } \\
\text { Agribusiness }\end{array}$ & atemu@dcl-tz.com \\
\hline
\end{tabular}




\section{Annex B: References}

Anim-somuah, H., Henson, S., Humphrey, J., and Robinson, E. (2013) Policy Guidelines: Enhancing Markets for Nutrient-Dense Foods in Ghana, IDS Evidence Report, Institute of Development Studies: Brighton, UK

Hystra. (2014) Marketing Nutrition for the Base of the Pyramid, Hystra

Maestre, M., Robinson, E., Humphrey, J., and Henson, S. (2014) The Role of Businesses in Providing Nutrient-Rich Foods for the Poor: A Case Study in Tanzania, Evidence Report, Evidence Report, Institute of Development Studies: Brighton, UK

Masters, W. A., Kuwornu, J., and Sarpong, D. (2011) Improving Child Nutrition through Quality Certification of Infant Foods: Scoping Study for a Randomized Trial in Ghana, Working Paper, London

Ogunmoyela, O. A., Adekoyeni, O., Aminu, F., and Umunna, L. O. (2013) 'A Critical Evaluation of Survey Results of Vitamin A and Iron Levels in the Mandatory Fortified Food Vehicles and Some Selected Processed Foods in Nigeria,' Nigerian Food Journal, 31.2: 52-62

Robinson, E., Akinyele, I. O., Humphrey, J., and Henson, S. (2014) Policy options for enhancing markets for nutrient-dense foods in Nigeria, Evidence Report, Institute of Development Studies: Brighton, UK

Robinson, E., Temu, A., Waized, B., Ndyetabula, D., Humphrey, J., and Henson, S. (2014) Policy options to enhance markets for nutrient-dense foods in Tanzania, Evidence Report, Institute of Development Studies: Brighton, UK

Temu, A., Waized, B., Ndyetabula, D., Robinson, E., Humphrey, J., and Henson, S. (2014) Mapping Value Chains for Nutrient-Dense Foods in Tanzania, Evidence Report, Institute of Development Studies: Brighton, UK

Waized, B., Temu, A., Ndyetabula, D., Robinson, E., Humphrey, J., and Henson, S. (2015) Promoting Biofortified Crops for Nutrition: Lessons from Orange-Fleshed Sweet Potato (OFSP) in Tanzania, Evidence Report, Institute of Development Studies: Brighton, UK 
Annex C: Impact Pathway Diagrams

Group A: Universal Salt Iodization

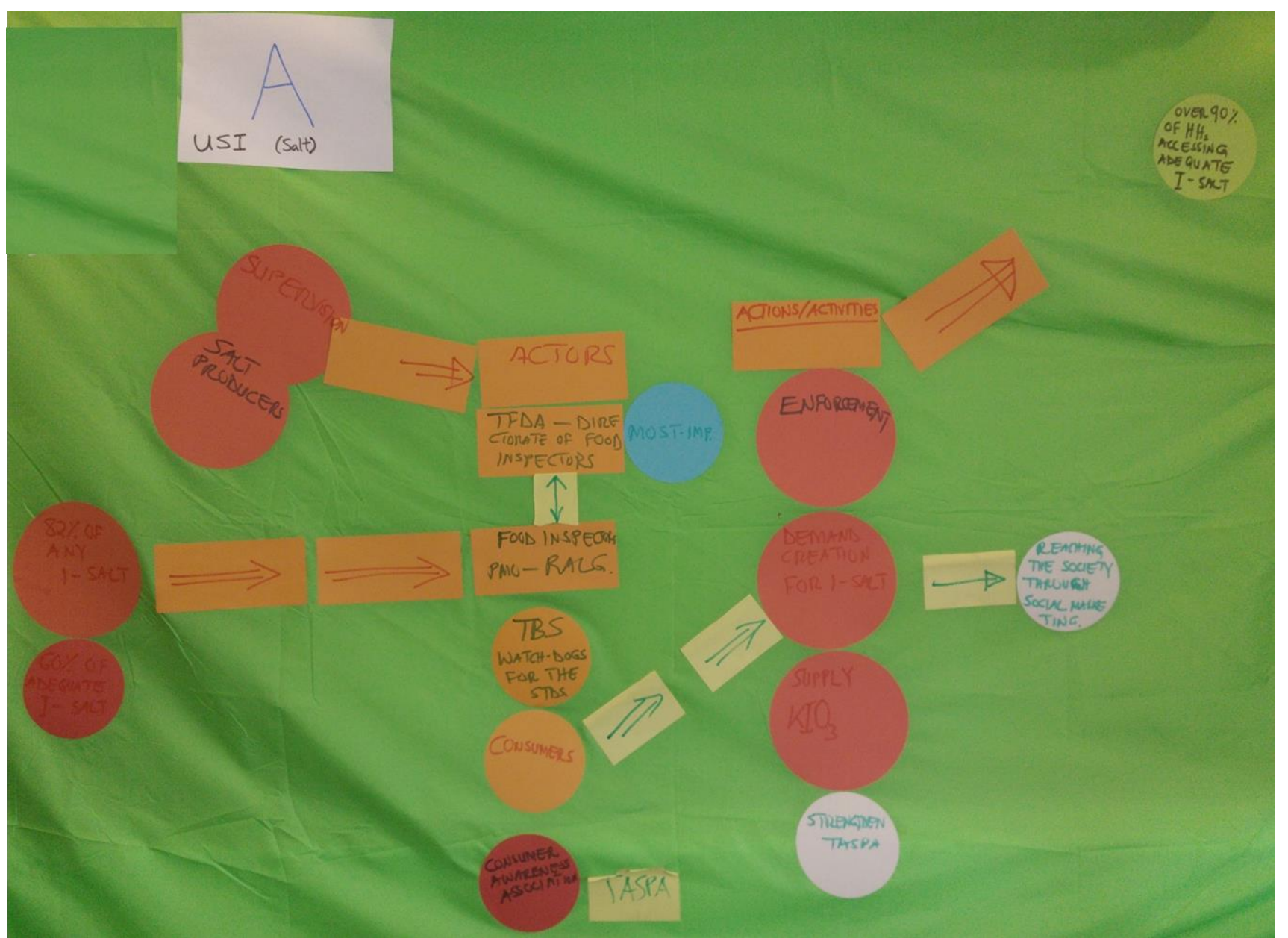


Group B: Sokoine University Graduates ECO (orange-fleshed sweet potato products)

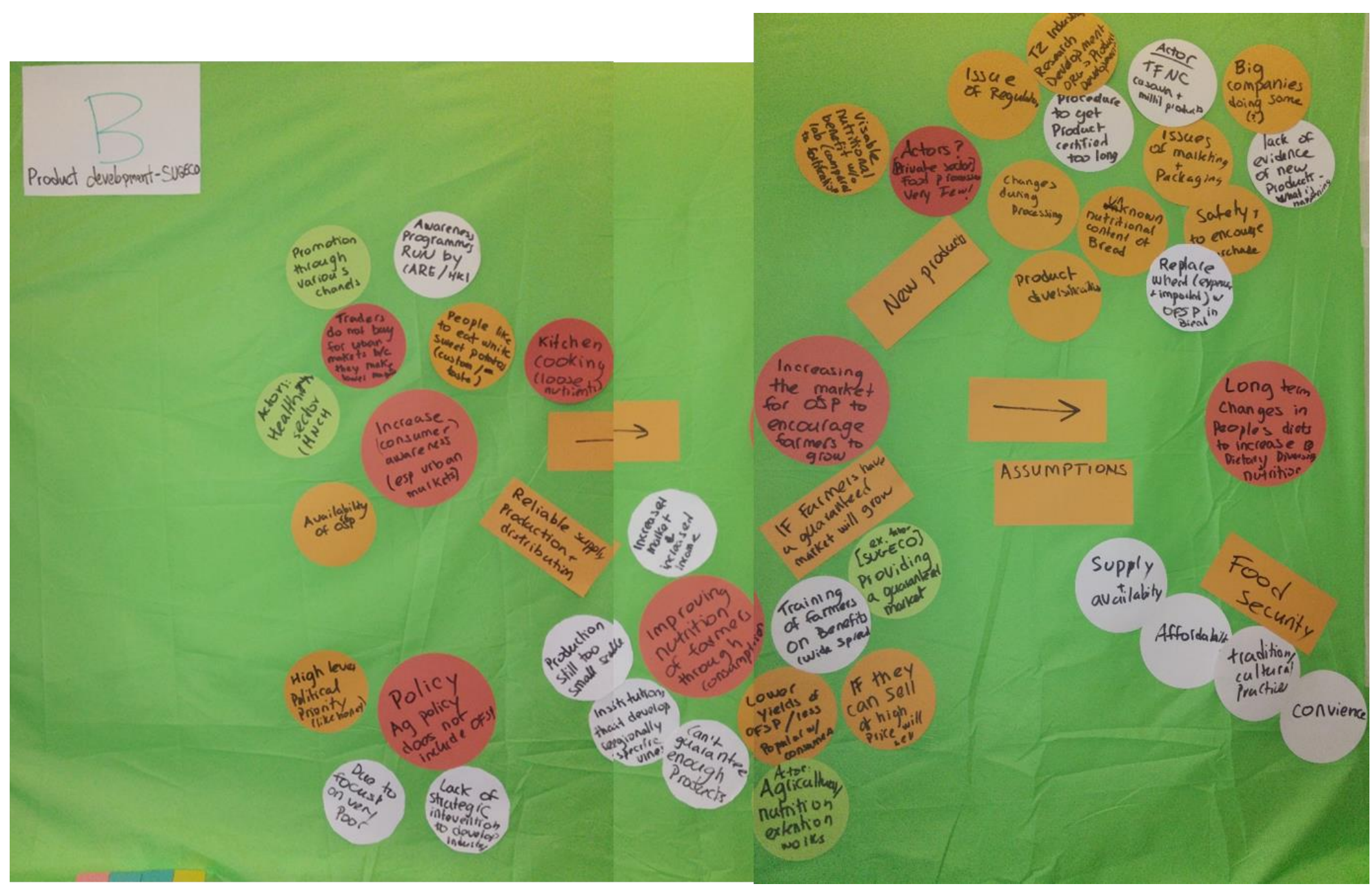


Group C: Rural Fortification Program

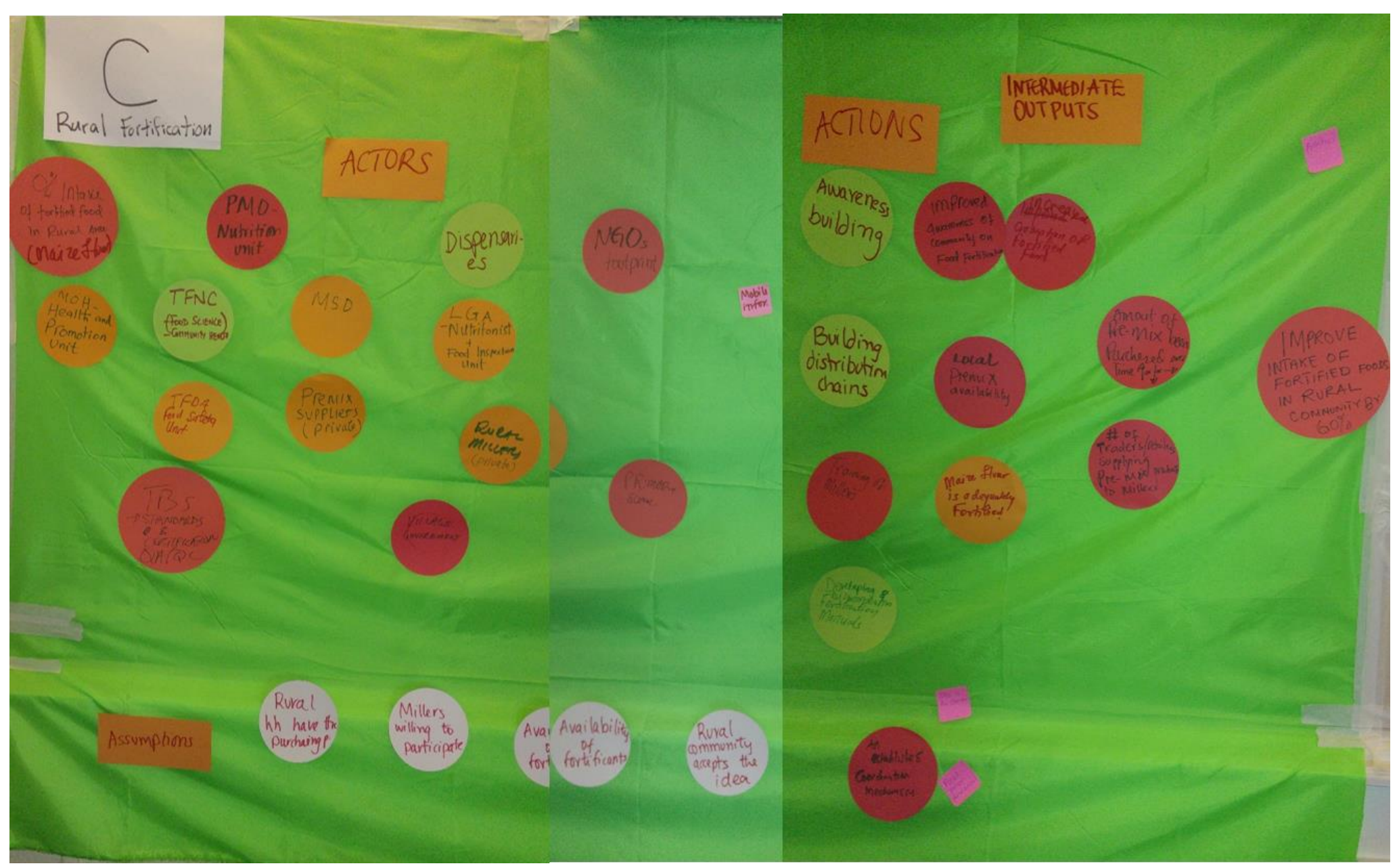


Group D: Tuboreshe Chakula Project

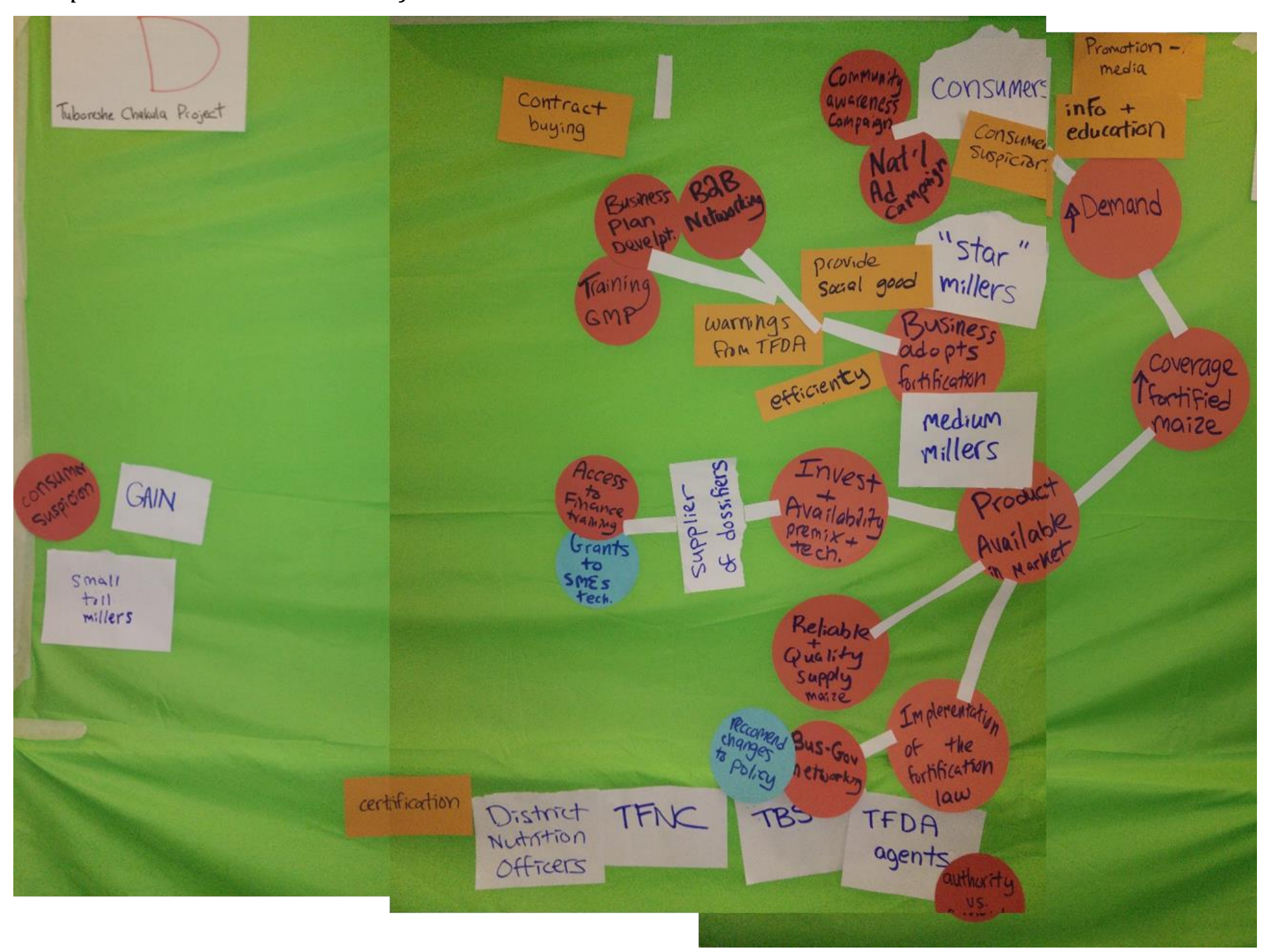

